\title{
バイオ研究者間の情報共有のためのプロテオーム XML 記述方式 An XML Format for Proteomics Database to Accelerate Collaboration among Bioresearchers
}

\author{
水口弘紀 $\dagger$ 上條 憲一 $\ddagger$ 次田 晧 $\ddagger$,* \\ Hironori MIZUGUCHI ${ }^{\dagger}$ Ken'ichi KAMIJO ${ }^{\ddagger}$ and Akira TSUGITA ${ }^{\ddagger, *}$
}

\begin{abstract}
プロテオーム解析におけるデータ共有のための XML 記述方式を提案する。ささらに，本 XML 記述を使ったプロトタイプを開発した。 プロテオーム解析は, 細胞内で発現している夕 ンパク質の網羅的同定やタンパク質の機能解明を目的とする。プロテオーム解析では, 解析 対象となる試料情報, タンパク質の分離手法, 解析結果である分離されたタンパク質名称, 機 能情報などを扱う。特に, 解析デー夕を共有，交換し，実験の再現や比較を行うには，実験 結果だけでなくタンパク質の分離手法などの実験手順情報も重要となる。我々は，バイオ研 究者間のデータ共有をより簡単に行うことを目指し，プロテオーム解析結果だけでなく，実 験手順情報も記述できるXML を用いたデー夕記述方法を提案する，さらに，実験手順に応 じて情報を入力し容易にXML データを作成できるエディタと，この XML データを登録検 索できるデータベースサーバシステムを開発した。
\end{abstract}

We propose an XML (eXtensible Markup Language) format for proteomics database to exchange proteome analysis data. The XML-based data is highly machine-readable and easy to represent information hierarchy and relationships. There have been several XML formats of proteome data which mainly represent the sequence information stored in the Protein Identification Resource (PIR) and the Protein Data Base (PDB). Our XMLbased data format has a proteome-analysis-oriented structure and describes information of sample preparation, 2D gel electrophoresis images, spot identification information in the gels and the sequence information of the spots. The model is used to exchange both of preparation parameters and the results of $2 \mathrm{D}$ gel electrophoresis analysis. It would accelerate collaboration among proteomics researchers if a platform exchanging these data is developed on the internet. By using the XML-based data format for proteomics, we have developed an XML editor and a web-based prototype system which consists of XML database, agent, security and graphical user interface (GUI).

キーワード：バイオインフォマティクス，プロテォーム解析，情報共有，XML，データベース Bioinformatics, Proteome, Information sharing, XML, Database

\section{1.はじめに}

近年, バイオテクノロジーやライフサイエ ンスの分野では，データベースを利用した情

$\dagger$ NEC インターネットシステム研究所, Internet Systems Research Laboratories, NEC Corporation, 奈良県生駒市高山町 8916-47

E-mail: hironori@ab.jp.nec.com

$\ddagger$ NEC 基碟研究所プロテオミクス研究センター, Proteomics Research Center, Fundamental Research Laboratories, NEC Corporation, 茨城県つくば市御幸が丘 34 番地

E-mail: k-kamijo@az.jp.nec.com

* E-mail: a-tsugita@ce.jp.nec.com
報蓄積, インターネットを利用した情報共有 を盛んに行っている。データベースのエント リー数も毎年増加しており, 遺伝子の公開デー タベースの DDBJ, EMBL, GenBank などで は，年に 2 倍のペースで増加している ${ }^{[1]}$ 。 バ イオ研究者は, 新たに発見した情報を論文発 表する前に，関連する遺伝子やタンパク質の 情報を公開データベースへ登録することが義 務付けられている場合が多く,データベースの 重要性は増す一方である. バイ才研究は,こ のような公開データベースを検索し, 新しい 
情報を取得し，取得した情報を利用して新た な発見が生まれる，というサイクルによって 発展していると言っても過言ではない.

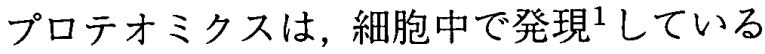
タンパク質（プロテイン）の網羅的な同定（夕 ンパク質名称のマイニングなど）や，タンパク 質立体構造の同定，タンパク質の機能解明な どタンパク質に関わる研究分野である．細胞 や組織などの試料から，タンパク質を分離し， 分離されたタンパク質の名前を同定し，機能 を調べることをプロテオーム解析と呼ぶ.夕 ンパク質は, 20 種類のアミノ酸を組み合わせ た一次元配列で表されており，その配列情報 やタンパク質の名前を知ることが，機能解明 の一歩となる。また, タンパク質は臓器や病 気に応じて細胞内に存在する種類が異なって いることがわかっており, 病気解明や創薬へ の利用が注目されている。タンパク質の種類 は非常に多く，たとえば，ヒトの場合，約 4 万種類の遺伝子から作られるタンパク質は選 択的スプライシングや修飾, 切断などの生化 学的な作用によって, 10 万種類以上存在する と言われている。研究者は，これらの遺伝子 やタンパク質データを公開データベースに登 録し, 共有することで, 調査対象の細胞に存 在するタンパク質の同定, その立体構造や機 能の解明につなげていく.

従来, バイオ分野で多く用いられてきたデー タフォーマットは, 特殊な例を除きテキスト ファイルであり，ほとんど構造を持っておら ず，データベース毎に記述方法も異なってい る。このようなデータは，一般のテキストエ ディタで編集することができ，研究者にとっ て見やすいという利点がある。しかし，コン ピュータ処理に必要なデータ交換のためには, データベース毎に特別な読込みなどの処理を 用意しなければならず，不向きである。

我々は，プロテオーム解析の結果などを研 究者間で共有し,プロテオミクスを促進させる ための XML 記述方法を提案した．XMLは，

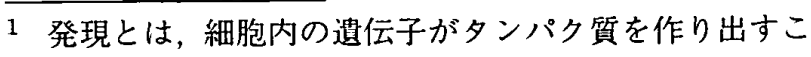
とをいう.
テキストファイルとしてデータを保存でき， しかも，構造化されているのでソフトウエア での処理も容易である。このため, 研究者が 見て理解でき，コンピュータ同士のデータ交 換にも適している。

提案する XML 記述方法の特徵は, 実験結 果のタンパク質データだけでなく，実験過程 （実験プロトコルとも呼ばれる）を記述できる 点である。プロテオーム解析における実験は， 実験の再現性が重要であり，実験に使われた 試薬や, 調合方法, 温度などの実験プロトコル に関する情報を記述することにより，実験の 信頼性を判断したり，追試を行ったりするこ とが可能となる。また，それらの情報がプロ テオーム解析の結果に付加されることにより, 解析結果の信頼性が向上したり, 自らの解析 結果との比較を行ったりすることができる。

さらに，提案するXML 記述方法を容易に記 述するエディタと，この XML データを登録， 検索し共有するためのデータベースサーバシ ステムを開発した。エディタは，プロテオー ム解析の実験手順毎に入力を行うことで簡単 にデータを作成できる，データベースサーバ システムは，検索項目を細かく指定可能であ り，実験結果だけでなく実験プロトコルに利 用した試薬までも検索可能である.

\section{2. プロテオーム解析のインフォマテ ィクスにおける課題}

プロテオーム解析は, 多くの公開データベー スを利用して，タンパク質の同定や機能発見を 行う。これら公開データベースのエントリー は，一般にフラットファイルフォーマットと 呼ばれる構造化されていないテキスト形式で 公開されている。タンパク質データベースで 世界的に有名な PIR ${ }^{[2]}$ と SWISS-PROT ${ }^{[3]}$ の エントリー例を図 1 に示す。左がPIR，右が SWISS-PROT のエントリーであり, 同じタン パク質データを表している，双方とも，各行 がデー夕項目をあらわしており, 行頭に項目 名, 次に空白, 次に項目内容を記述している. 
PIRの内容は以下である. 1 行目に識別子, 2 行目にタンパク質の機能概要を示す意味のわ かる夕イトル， 3 行目か: 5 行目に生物種名と 生物種データベースへの参照, 6 行目から 8 行 目にデータベースエントリーの作成更新日時, 9 行目にデータベースへアクセスするための 番号, 10 行目から論文などへの参照, 次にアミ ノ酸配列が示されている.SWISS-PROT の 内容は以下である. 1 行目に識別子, 2 行目 にデータベースへアクセスするための番号, 3 行目から 5 行目に作成更新日時, 6 行目に機 能概要, 7 行目に関連遺伝子名, 8 行目に生物 種, 次に参照情報, アミノ酸配列情報が示さ れている。

この例から次の二つの課題が挙げられる.

・データフォーマットが異なる

- 実験過程情報の欠如

図 1 のつのデータベースのデータフォー マットは, 各行がデータ項目を表すことや, 識 別子, 論文への参照, アミノ酸配列を持つこと などの共通性はあるものの, 項目の数や順序 も異なり, 項目の意味は同じであるが項目名 が異なっているなど記述形式が異なる。この ようにフォーマットが異なっていると，デー 夕内容や項目の違いを理解せねばならず研究 者間でのデータ交換を行って，コンピュータ で管理することは難しいと思われる。研究者 間で同じフォーマットのデータ，もしくは，
フォーマットが簡単に変換できるデータを共 有する必要がある.

一般にデータベースのエントリー内容は, 実験対象となる生物種や組織名, 機能, 発表 論文への参照など実験結果や解析結果の情報 のみであり，実験過程の情報は多種多様な手 段を用いているため含まれていない。実験過 程は，実験結果や解析結果データの信頼性の 判断や実験結果の比較のためには必要である. 特に, プロテオーム解析では，実験に利用す る試薬は研究者ごとに異なる場合があり，実 験対象が同じであっても試薬の違いによって 実験結果が異なる。したがって，どのような 手順，試薬を利用したか明確に記述すること は，実験結果の信頼性を向上させる上で必要 である。

\section{3. 課題解決へのアプローチ}

これらの二つの課題に対し，実験過程を記 述できるプロテオーム XML 記述形式を提案 する．XML で記述することで，データ共有に 利用しやすいフォーマットとなり, フラット ファイルの課題を解決できる。XMLの特徴 である，人間も計算機も読み書き可能である 点, データ交換の容易さ, XSLTを利用した デー夕構造の簡単な変換ができることなどを 有効に活用することができる。さらに，提案

\begin{tabular}{|l|}
\hline ENTRY $\quad$ xxxxx \\
TITLE G protein-coupled $x x x x$ \\
ORGANISM \\
\#formal_name Caenorhabditis elegans \\
\#cross-references taxon:6239 \\
DATE 29-0ct-1999 \\
\#sequence_revision 29-0ct-1999 \\
\#text_change 29-0ct-1999 \\
ACCESSIONS xxxx \\
REFERENCE 221511 \\
\#authors (省略) \\
(省略) \\
SEQUENCE \\
(省略) \\
\end{tabular}

\begin{tabular}{l} 
ID $\quad x x x x$ \\
AC $x x x x$ \\
DT $01-$ NOV-1995 (ReI. 32, Created) \\
DT 15-DEC-1996 (Rel. 33, Last sequence update) \\
DT (省略) \\
DE Serpentine receptors xxxx \\
GN SRG-9 OR T12A2.10. \\
OS Caenorhabditis elegans. \\
(省略) \\
RN [1] \\
RP SEQUENCE FROM N.A. \\
RC STRAIN=(省略)： \\
RA (省略) \\
SO \\
(省略) \\
\hline
\end{tabular}

図 1: タンパク質データベース PIR（左）とSWISS-PROT（右）のエントリー例 (図中“(省略)”の部分は紙面の都合のため省略) 
する記述方式には実験結果だけでなく，実験 過程も記述できるため，実験の比較や妥当性 の検証などを行うことができる。

最近，バイ才分野ではデータベース間での フォーマットの違いを吸収するため, 公開デー タベースのエントリーを XML で記述するこ とが行われている。また，データ解析ソフト ウエアでの XML 利用も行われている。

遺伝子データベース GenBank ${ }^{[4]}, \mathrm{EMBL}^{[5]}$, $\mathrm{DDBJ}^{[6]}$, タンパク質データベース $\mathrm{PIR}^{[2]}$ は, データベースエントリーをXML で提供する サービスを開始している。これらは，既存の データエントリーをXML で記述しユーザに 提供している。しかし，これらには，実験過 程があまりに多種多様なため，実験を再現す る実験過程情報は含まれていない。

データ解析ソフトウエアで利用するために 独自に決めたXML記述方法として, BSML ${ }^{[7]}$,

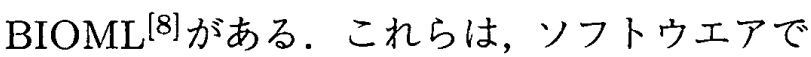
独自に決めたフォーマットであり，主に遺伝 子塩基配列やタンパク質アミノ酸配列データ を格納するために用いられる。データは配列 データのみである。

実験過程の情報をXML 化しょうという試 みは, プロテオミクスの分野ではなく, 遺伝子 の発現解析の分野で行われている。たとえば, デー夕解析ソフトウエアと実験機器で交換す るための XML 記述方法として MAGE-ML ${ }^{[9]}$
がある。これは，遺伝子解析用の実験機器であ るマイクロアレイに用いられるフォーマット であり，実験結果を解析するためのソフトウエ アとのデータ交換が目的である．MAGE-ML には，実験過程情報も含まれているが，遺伝 子の機能などを解析するゲノム研究に適用す るフォーマットであり, マイクロアレイ機器 に特化したフォーマットである。

\section{4. プロテオーム解析の実験プロトコ ル}

プロテオーム解析は, 創薬や診断のマーカー のための標的タンパクを探したり，興味ある 組織で発現しているタンパク質を網羅的に調 べたりする目的で使われる，例えば，正常細 胞で発現しているタンパク質と疾患細胞で発 現しているタンパク質の集合を比較して，標 的タンパク質を探したり，同じ組織でも，時 間的経過によるタンパク質発現の変化を調べ たりすることができる。

図 2 にプロテオーム解析の実験過程の一例 を示す。一般に，プロテオーム解析は，タン パク質を分離するための二次元電気泳動法や 液体クロマトグラフィ法，タンパク質を同定 するためのペプチド・マス・フィンガープリ ント法, ペプチド・シーケンス・タグ法, $\mathrm{N}$ 末端シーケンシング法, $\mathrm{C}$ 末端シーケンシン

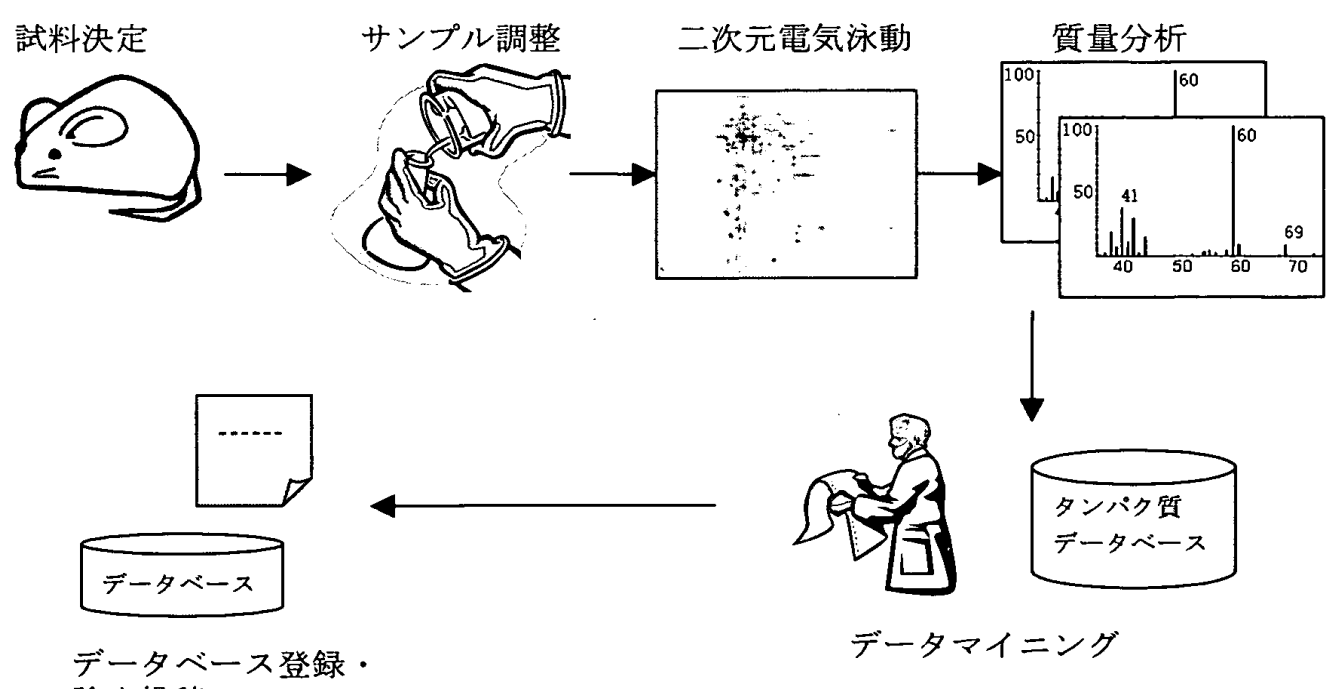

図 2: タンパク質同定における実験過程 
グ法, フラグメントペプチドのマス/マス分 析で，そのペプチドの両末端のシーケンス法 などを行う. 以下では, 二次元電気泳動法と, ペプチド・マス・フィンガープリント法を用 いた実験過程を説明する。

研究者は, 最初に, 研究ターゲットとなる 試料を決定する。試料とは，発現している夕 ンパク質を調べたい細胞や組織である。研究 対象となるヒトやイネといった生物種, 肝臓 や腎臓, あるいは葉や根といった部位, 病気 や発芽といった状態から試料を決定する。

次に, 試料からサンプル調整を行う。サン プル調整とは, 試料となる細胞や組織から夕 ンパク質を溶液中に抽出する工程である。細 胞は細胞膜に覆われているため種々のデター ジェントを用いたり超音波などを用いて破壊 し，さらに，細胞にはタンパク質以外の物質 も含まれているため様々な試薬や遠心分離機 などを利用して分離抽出する。詳細は, 参考 文献 [10][11][12]に紹介されている。試料に応じ て, 適切な細胞破壊の方法やタンパク質抽出 の試薬などがある.

サンプル調整で得られたサンプルには多く
の種類のタンパク質が溶け込んでいるため, 次にこれらを二次元電気泳動法によりタン パク質を性質別に分離する。サンプルを電荷 と分子量というタンパク質の性質別に分離す るのが二次元電気泳動法であり，これにより 3000 種類以上のタンパク質を一度に分離でき る.この実験は 4 つのステップに分かれる. 1) サンプルを流し入れ棒状ゲルに接触させ, ゲルの両端に電極を付け, 適切な電圧をかけ る。これにより，タンパク質は電荷に応じて 対応する位置に移動する。2) 垂直に立てた平 面状のゲルに，この棒状のゲルをのせ，上下 に電圧をかける。これにより分子量の違いに よってタンパク質の移動速度が異なるため, 小さいタンパク質が下に，大きいタンパク質 が上になるように展開される．3）タンパク質 を可視化するために，たとえば銀染色とよば れる方法でタンパク質を染め, このゲルをイ メージスキャナで読み取る.4) 分離された夕 ンパク質の位置を認識ソフトウエアで解析す る。この詳細は, 参考文献 [10][11][12]に紹介さ れている。この結果の例を図 3 に示す。横軸 に電荷 (Isoelectric Point) ごと, 縦軸に分子

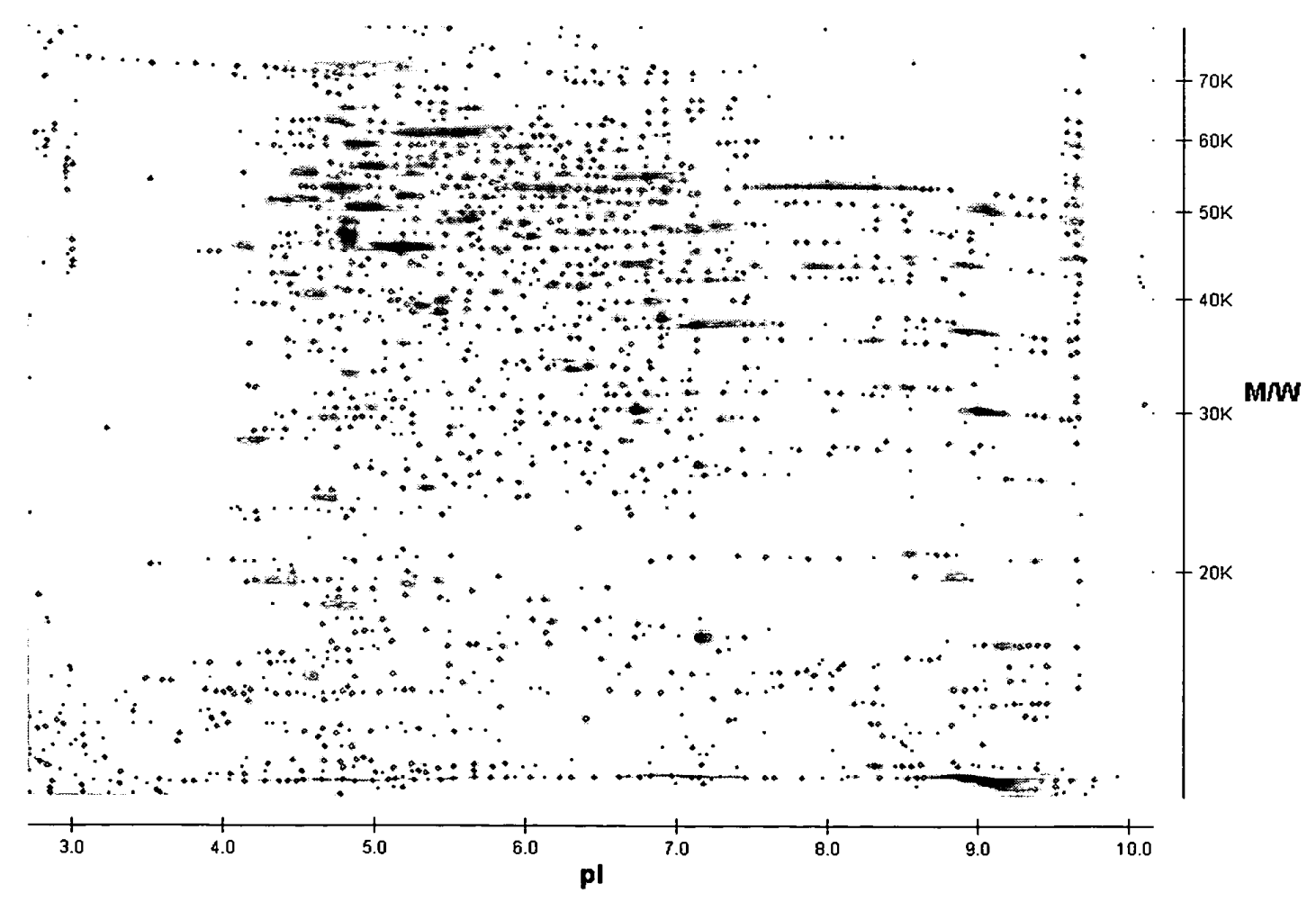

図 3: C.elegans（線虫）の二次元電気泳動結果 
量 (Molecular Weight)ごとのタンパク質が分 離されている。黑茶色に染まった部分が分離 されたタンパク質の集まりであり，これをス ポットと呼ぶ.この画像を手順 4) の認識ソフ トウエアで処理することで，各スポットの位 置が自動または手動で認識される.

解析対象となるスポットを決めると, 次は, 質量分析実験によりそのスポットのタンパク 質の同定を行う。二次元電気泳動法により平 面状ゲルに分離したタンパク質のスポットに 対し, ペプチド・マス・フィンガープリント 法と呼ばれる方法を使って詳細な質量を分析 する。まず，各スポットをゲルから一つずつ 切り出す．次に，消化酵素（トリプシンなど） を用いてタンパク質をアミノ酸配列の特定位 置で切り離す。分割されたタンパク質断片を 質量分析器で計測して，分割されたそれぞれ の質量位置にピークがある質量スペクトルを 得る.

タンパク質の同定は, 既存のタンパク質デー タベースを用いたデータマイニングにより行 う。データベース中のタンパク質に消化酵素 を適用した場合の質量スペクトルを，コンピ ユータで計算する。この計算結果と観測され た質量スペクトルが同じパターンであれば, そのタンパク質であると決定する。同じ性質 を持ったタンパク質は複数存在する場合があ るため, 複数の候補の中から研究者が似た生 物種や部位などを判断し，タンパク質を同定 する.

これら実験を繰り返し, 研究ターゲットと なる状態から，タンパク質の機能を推定し論 文などで発表する。

\section{5. プロテオーム XML}

プロテオミクス研究者の情報共有を容易に 実現し, 研究を促進させるために, XMLを利用 したデータ共有フォーマットを提案する。こ の XML フォーマットの特徴は, Simpson ${ }^{[13]}$ ら, および, 次田 ${ }^{[14]}$ の提案した, データベー スに必要と考えられる解析結果情報に加えて, 実験過程も記述することが可能である.

\subsection{XML 記述方式}

提案する XML 記述はプロテオーム実験プ ロトコルに対応した構造を持っている。おお まかな構造を図 4 に示す。それぞれの項目は, 4 節で示した実験プロトコルに対応している。

一連の実験をまとめるルート項目 “Proteome”の直下に項目 “Gel”を記述する．項 目“Gel”は一回の実験過程や実験結果を示す 項目である。研究者は同じ試料に対して複数 回の実験を行ったり，正常や疾患の違いを比 較したりすることに対応するため, 項目 “Gel” は複数記述することができる。

項目 "Gel”の下には, 項目 "Submitter", "Source info.", "Sample Preparation", "Gel Conditions", "Gel Image", "Spot List" が ある。

項目 "Submitter" は実験者や記述者の名前 などである. 項目 “Source Info." は, 研究夕ー ゲットとなる試料情報であり生物種や部位の 名前などである。項目 "Sample Preparation” は, サンプル調整方法であり, 細胞の破壊方 法やタンパク質抽出に使用した試薬などの情 報を記述する。項目 “Gel Conditions”は, 二

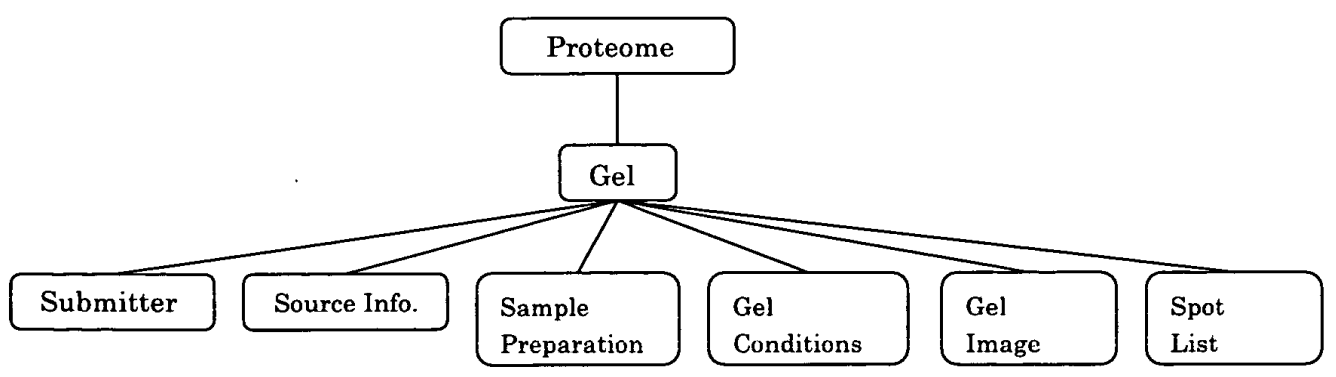

図 4: プロテォーム XML の構造 


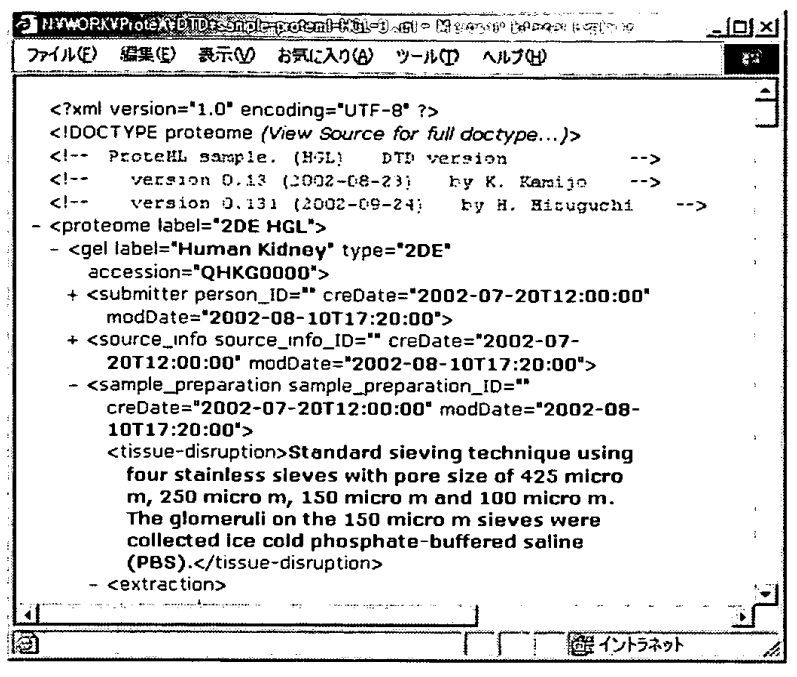

図 5: "Sample Preparation"

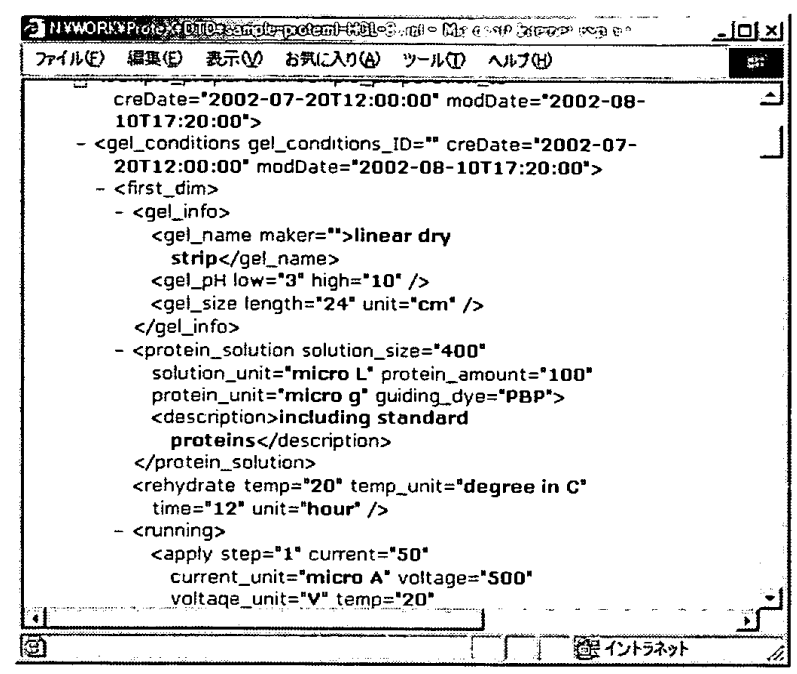

と "Gel Conditions"（右）の記述例
次元電気泳動時の電圧などの条件やゲルを調 整するために利用した試薬などである。項目 “Gel Image" は，画像情報であり画像サイズ， 利用したイメージスキャナ名称などを記述す る. 項目 "Spot List”は, 各スポットの情報 である。この項目の下には，二次元電気泳動 結果のスポット位置や, 質量分析器の解析結 果, タンパク質名称などを記述できる.

項目 "Sample Preparation" と項目 "Gel Conditions" の例を図 5 に示す.このように, 我々の XML 記述方式は, 他のプロテオーム 記述方法と異なり, 実験過程を細かく記述で きる。

これらの構造は XML で記述することによ り，データ交換に適した汎用性の高いフォー マットとなっている. XML はテキストファイ ルとしてデータを保存でき，しかも，ソフト ウエアでの処理方式も決まっているため，人 が見て理解でき，コンピュータ同士のデータ 交換にも適している。また，デー夕共有に必 要なデー夕交換の容易さや，XSLTを利用し たデー夕構造の変換といった点も活用できる.

\section{2. プロトタイプシステム}

このような記述を有効に利用するためのプ ロトタイプを開発した.このプロトタイプは,
我々のプロテオーム XML 記述にしたがって データを記述できるエディタと, XML デー 夕を登録検索できるデータベースサーバから なる。

\section{プロテオーム XML エディタ}

プロテオーム XML エディタは, プロテオー ム実験プロトコルに対応した入力インタフェー スを持ち，各種データインポート機能を持つ ことにより，プロテオーム XML 記述に対応 したデー夕を容易に作成することができる。 XML エディタの適用例を図 6 に示す。提案 したXML 記述方式は, 実験過程を明確に記 述できるが，これにしたがって記述するため には, 試薬名称, 適用順序など多くの入力を 必要とする。本 XML エディタは，このよう な入力作業を軽減することを目的としている.

本 XML エディ夕は実験プロトコルに従っ て記述することで，容易にデータを作成する ことができる．左側のツリービューの各項目 は上から順番に実験プロトコルの各ステップ を示している.ツリービューのステップを選 択することで, そのステップで必要な入力項 目を表示する. 入力項目は夕ブで示され，各 タブはより詳細な実験手順を示している。さ らに，再利用可能なデー夕をエキスポートし たり，インポートしたりすることができる。 たとえば，同じ生物種の同じ部位の細胞であ 


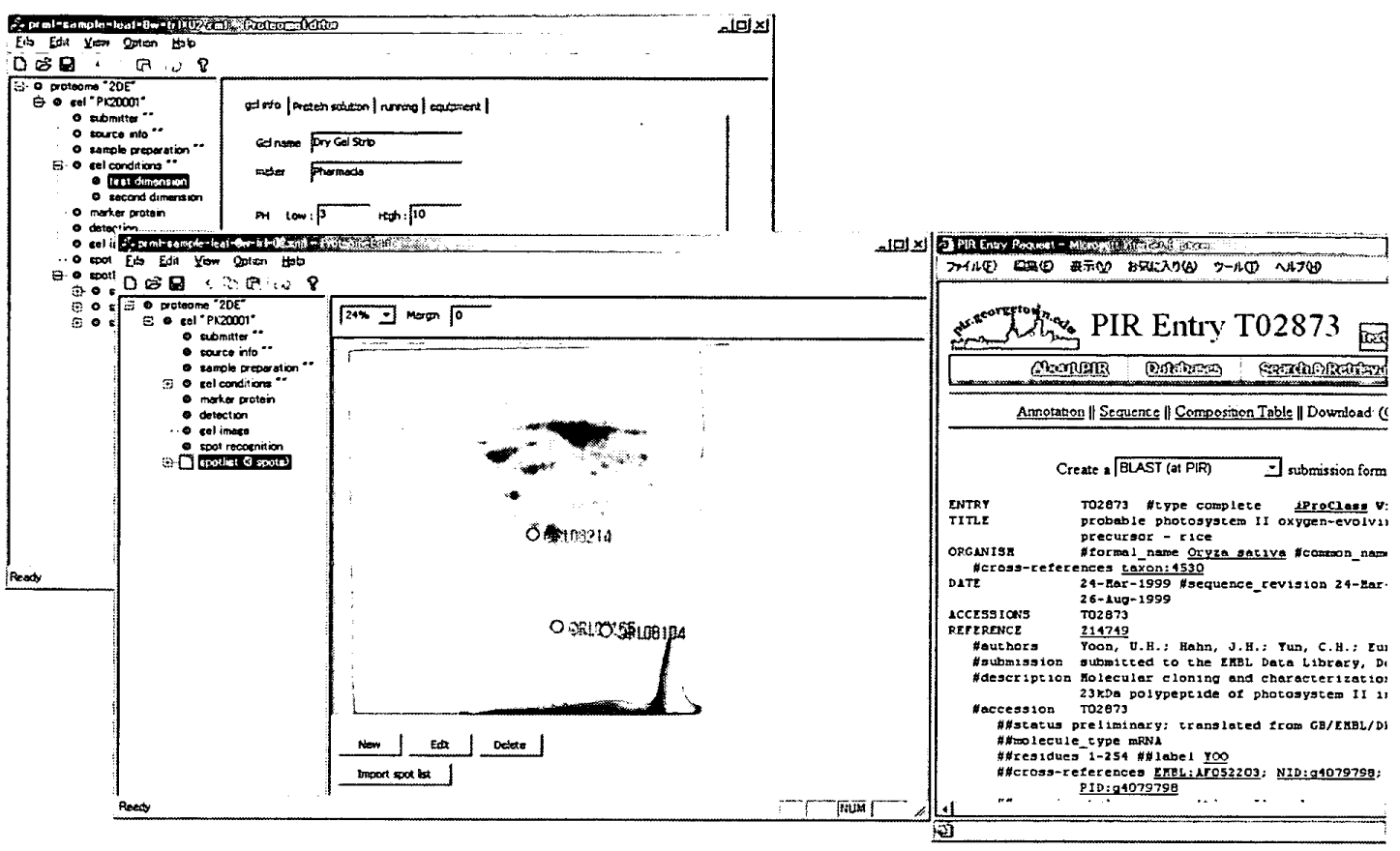

図 6: エディタ画面例

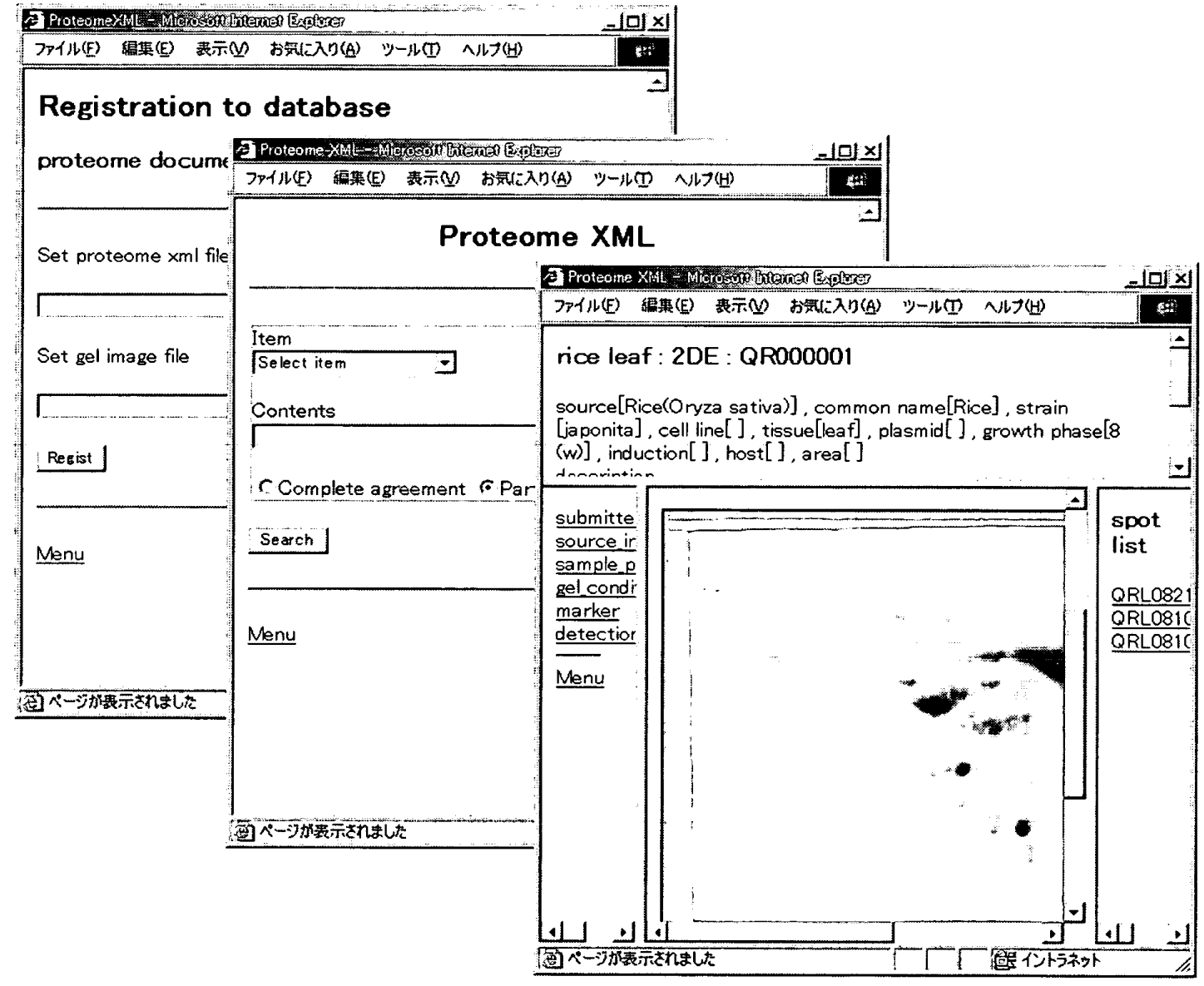

図 7: データベースサーバ例 
れば，そのサンプル調整方法は同じ場合が多 い.このエディタでは，一度記述したサンプ ル調整方法を XML 形式で保存し，再度読み 出すことができる。また，質量分析器などの 解析機器のデー夕を読み込むことで，入力の 手間を軽減することができる。

さらに, 二次元電気泳動結果の画像上にス ポットを表示でき, 各スポットのデータはデー タベースへのリンクとなっている．研究者が 同定したタンパク質の公開データベース名と エントリー識別子を入力し，ボタンをクリッ クすることでデータベースエントリーをすぐ に閲覧することができる。

\section{XML データベースサーバ}

データベースサーバは，複数のプロテオー ム XML データからタンパク質の名称や, 生物 の名称だけでなく，利用した試薬の名前など も利用して検索することができ，必要であれ ば対象となるXMLデータを表示したり，ダウ ンロードしたりすることも可能である。デー タベースサーバのアクセス例を図 7 に示す.

試薬まで検索できることにより, 同じ生物や 同じ部位について研究している研究者がどの ような試薬を用いてプロテオーム解析を行っ ているかなどを検索することもできる。これ により，実験結果の比較が可能であるかを判 断することや，実験の妥当性を検証するため に追試を行うといったことが, 別な研究者でも 可能となる．ダウンロードできることで，前 述のエディタのインポート機能と共に利用す れば，別の研究者の試薬デー夕を利用して自 分の実験を行うこともできる。

\section{6. まとめ}

プロテオーム解析の結果だけでなく実験過 程も記述できるXML 記述方式を提案し，プ ロトタイプシステムを作成した．XML 記述 方式はサンプル調整などプロテオーム実験プ ロトコルを反映したものである．XMLを利 用することでデータ共有を容易に行うことが
できる．プロトタイプシステムは，XML 記述 デー夕を簡単に作成できるエディ夕, XML 記 述データを登録検索するデータベースサーバ を作成した。

今後この XML 記述方式における $\mathrm{DTD}^{[15]}$ やXML Schemaを, プロテオミクス研究者の 国際組織である AOHUPO(Asia Oceania Human Proteome Organization) と共に決定し, XML エディタを配布する予定である。

\section{謝辞}

論文執筆にあたり，ご助言をいただいた NEC インターネットシステム研究所の久寿 居大氏に感謝いたします。

\section{参考文献}

[1] 日本 DNA データバンク: DDBJ の統計 $\lceil\mathrm{DDBJ} / \mathrm{EMBL} /$ GenBank database 塩 基配列の推移」, http://www.ddbj.nig. ac.jp/ddbjnew/statistics-j.html（2002 年 10 月 25 日参照).

[2] National Biomedical Research Foundation, Georgetown University Medical Center: "PIR(Protein Information Resource)", http://pir.georgetown.edu/ (2002 年 10 月 25 日参照).

[3] Swiss Institute of Bioinformatics: "SWISS-PROT Protein knowledgebase", http://tw.expasy.org/sprot/ (2002 年 10 月 25 日参照).

[4] National Center for Biotechnology Information: "XML at NCBI", http://www.ncbi.nlm.nih.gov/IEB/ ToolBox/XML/ (2002 年 10 月 25 日 参照).

[5] European Bioinformatics Institute: "The XEMBL Project", http://www. ebi.ac.uk/xembl/（2002 年 10 月 25 日 参照). 
[6] 日本 DNA データバンク: “XML Central of DDBJ", http://xml.nig.ac.jp/ index.html (2002 年 10 月 25 日参照).

[7] LabBook inc.: "BSML (Bioinformatic Sequence Markup Language)", http://www.bsml.org/ (2002 年 10 月 25 日参照).

[8] Proteometrics, LLC and Proteometrics Canada Ltd: "BIOML (BIOpolymer Markup Language)", http://www. bioml.com/BIOML/index.html (2002 年 10 月 25 日参照).

[9] Microarray Gene Expression Data Society: "MAGE-ML (Microarray Gene Expression - Markup Language)", http://www.mged.org/Workgroups/ MAGE/mage.html（2002 年 10 月 25 日 参照).

[10] 礒辺敏明, 高橋信明 編: 「プロテオーム 解析法 タンパク質発現・機能解析の先端 技術とゲノム医薬・創薬研究」, 羊土社, $282 \mathrm{p}, 2000$.

[11] 岡田雅人, 宮崎香 編：「改訂タンパク質
実験ノート上抽出と分離精製」, 羊土社, $191 \mathrm{p}, 2002$.

[12] 岡田雅人, 宮崎香 編 :「改訂タンパク質 実験ノート下分離同定から一次構造の 決定まで」，羊土社，163p，2002.

[13] Simpson, R.J.; Tsugita, A.; Celis, J.E.; Garrels, J.I.; Mews, H.W. : "Workshop on two-dimensional gel protein databases", Electrophoresis 13, pp.1055 $-1061,1992$.

[14] 次田晧：「ポストゲノムにおけるプロテ オーム研究」, 情報知識学会誌, Vol.10, No.4, pp.32-42, 2001.

[15] Kamijo, K.; Yamazaki, T.; Tsugita, A: "A Proposition of XML Format for Proteomics Database", Proc. Of 18th International CODATA Conference, p.50, 2002.
(2002 年 11 月 14 日受付) (2002 年 11 月 30 日採録) 